Jurnal Ekonomi Syariah Teori dan Terapan p-ISSN: 2407-1935, e-ISSN: 2502-1508. Vol. 8 No. 6

November 2021: 757-770; DOI: 10.20473/vol8iss20216pp757-770

\title{
PRODUCTIVE WAQF DEVELOPMENT THROUGH IJARAH CONTRACTS IN RELIGIOUS EDUCATION INSTITUTIONS IN JOMBANG, EAST JAVA
}

\section{PENGEMBANGAN WAKAF PRODUKTIF MELALUI AKAD IJARAH DI LEMBAGA PENDIDIKAN KEAGAMAAN DI JOMBANG, JAWA TIMUR}

\author{
Imam Azizuddin ${ }^{D}$, Ilyas Nurul Azam \\ Perbankan Syariah-Fakultas Ekonomi UIN Maulana Malik Ibrahim \\ Ekonomi dan Bisnis Islam STAI At-Tahdzib \\ imamazizuddin@uin-malang.ac.id*, ilyasnurulazam@gmail.com
}

\begin{abstract}
ABSTRAK
Penelitian ini membahas secara mendalam terkait penerapan wakaf produktif di lembaga pendidikan agama TPQ dari perspektif madzhab Syafi'i. Penelitian ini diklasifikasikan sebagai penelitian kualitatif karena data yang digunakan bersifat kualitatif. Yakni, informasi yang diperoleh dari Kepala $T P Q$, nadzir, dan penyewa yang menjadi pemikiran atau pemahaman mereka tentang objek atau topik tertentu, dalam hal ini, adalah pengembangan kontrak ijarah di tanah wakaf. Penelitian ini menunjukkan perkembangan wakaf produktif melalui perjanjian ijarah di lembaga pendidikan agama dalam bentuk TPQ yang sudah memenuhi syarat dan rukun ijarah menurut madzhab Imam Syafi'i. Hal ini dibuktikan karena, dari transaksi atau perjanjian tersebut, nazir telah menggunakan tenggat waktu per tahun. Selain itu, sudah ada juga kesepakatan dari awal bahwa tanah wakaf yang disewa digunakan untuk melakukan bisnis perdagangan. Dan sewa tempat itu hanya sementara, bukan untuk selamanya. Penelitian ini dapat menjadi masukan bagi praktisi ekonomi syariah untuk dapat mengembangkan wakaf produktif secara optimal dengan model ijarah serta menjadikan wakaf produktif di TPQ sebagai model pengembangan wakaf produktif yang sangat potensial di Indonesia.
\end{abstract}

Kata Kunci: Wakaf produktif, ijarah, Pendidikan keagamaan, madzhab Syafi'i.

\author{
Informasi artikel \\ Diterima: 25-08-2021 \\ Direview: 08-10-2021 \\ Diterbitkan: 30-11-2021 \\ ${ }^{*}$ Korespondensi (Correspondence): \\ Imam Azizuddin \\ Open access under Creative \\ Commons Attribution-Non \\ Commercial-Share A like 4.0 \\ International Licence \\ (CC-BY-NC-SA)
}

\section{ABSTRACT}

This research discussed the application of productive waqf in the $T P Q$ (Al-Qur'an Learning Centre) religious education institution from the perspective of the Syafi'i school of thought. This research was classified as qualitative research because it used qualitative data, namely the information obtained from the Head of TPQ, nadzir, and tenants that became their thoughts or understanding of a particular object or topic, in this case, was the development of an ijarah contract on waqf land. This research showed the productive waqf development through ijarah agreements in religious educational institutions in the form of TPQ that had fulfilled the requirements and pillars of ijarah according to the Imam Syafi'i school of thought. It was proven that Nazir had used the deadline per year from the transaction or agreement. In addition, there was also an agreement from the beginning that the leased waqf land was used to conduct trading business. Furthermore, the lease of the place was only temporary, not forever. This research can be an input for practitioners of Islamic economics to develop productive waqf optimally with the ijarah model and make productive waqf in TPQ as a model for developing productive waqf with great potential in Indonesia.

Keywords: Productive Waqf, Ijarah, Religious Education, Shafi'i madhhab.

\section{INTRODUCTION}

Humans are God's perfect creation. In their life, humans cannot be separated from the help of others; therefore, humans are called social creatures. Islam teaches us to help each other. A wealthy person must help his poor brother. The help can be in the form of a given, such as zakat, infaq, sadaqah, waqf. 
Waqf has helped a lot in the development of various sciences, both religions, and other sciences. Usually, the results of waqf property management are used to build public facilities in religion, health, education, the construction of TPQ, hospitals, libraries, buildings, and others. Referring to the data on waqf land registered with the Indonesian Ministry of Religious Affairs (Kemenag), there are 54,394.49 hectares (ha) of waqf land spread over 406,632 locations throughout Indonesia. This large amount of waqf land is the largest waqf property in the world. Unfortunately, most of the waqf land has only been used for the TPQ's welfare (72.3\%), graves $(4.5 \%)$, orphanages $(8.9 \%)$, and educational facilities $(14.3 \%)$. Only a tiny part is managed in a more productive direction. Waqf assets are usually more unproductive $(77 \%)$ than productive $(23 \%)$. Waqf in Indonesia has significant assets but has not been optimized(Kemenag, 2021).

Waqf is usually done by setting aside some of the wealth for goodness and benefit, whether it is intended for certain people, such as poor people, travelers, or seekers of knowledge, or intended for the public interest. Therefore, scholars have never distinguished between a person's waqf for his family members and waqf carried out for the public interest(Hafidhuddin \& Antonio, 2004).

Discussion about waqf is often directed to immovable waqfs, such as waqf that is handed over to build TPQ, schools, bridges, hospitals, orphanages, etc. Besides those forms of waqf, there is also productive waqf. The empowerment of productive waqf is not only profit-oriented but also provides economic and social benefits(Fahri \& Zaki, 2018).

In this context, it is crucial to link productive waqf management and development activities with religious educational institutions. In this research, the religious education institution was the AlIslamiyyah Al-Qur'an Learning Centre (TPQ) of Jombang, which stood on waqf land and implemented productive waqf. In this case, the productive waqf was in the form of a buying and selling area to provide snacks for students who recited the Qur'an at the TPQ. It was developed to provide people who wanted to be entrepreneurs as a form of seeking family economics.

The development of productive waqf that was leased had not been known whether the proceeds from these efforts would be included in the TPQ budget or into other budgets because the lease had only been done for five years. If the current lease has been paid and the budget is included in the development treasury of the TPQ institution. Due to the TPQ, there are always improvements. Meanwhile, the budget from the lease still has not been known what will be used in the future.

The term of the lease is one year. If in one year it has not been paid, the tenant must leave the place. It was an agreement from the beginning of the lease. The lease payments are paid in advance before occupying the place. The pillars and terms of the lease are correct with the existing theory.

In this research, more field observations were carried out in detail and focused on a particular object related to all research data. The field research was an in-depth study of specific social units that provided an overview of the results of broad and in-depth research on a particular social unit(Oktarina \& Asnaini, 2018; Sudarwan, 2002).

Based on research by Amimah Oktarina (2018), it was concluded that the productive waqf that Agung Martir Al-Qur'an Learning Center has provided many sustainable contributions both internally and externally. The endowment funds collected from productive waqf activities were appropriately managed and professionally so that the distribution could be carried out correctly, meaning that the endowments were channeled productively by developing them in several business areas in Agung Syuhada Al-Qur'an Learning Center of Yogyakarta(Oktarina \& Asnaini, 2018).

Research by Mohammad Akhir (2019) reported that most of these Private Tahfidz Schools (STS) were founded on waqf funds. However, the waqf property was significantly less to be developed for use. Therefore, it was recognized that the ijarah instrument could be applied to obtain financial benefits for the STS's sustainability in Malaysia.(Mohamad Akhir et al., 2019).

Based on the explanation above, this research discussed the application of productive waqf in TPQ religious education institutions from the perspective of the Shafi'i school of thought. Thus, it can be input for practitioners of Islamic economics to develop productive waqf optimally by making productive waqf in TPQ as a model for developing productive waqf with great potential in Indonesia. 


\section{LITERATURE REVIEW}

\section{ASy-Syafi'iyah perspective of ijarah contract}

The Shafi'i madhhab is one of the four madhhabs that are made guidelines for the application and implementation of sharia law in Islam. Indonesia, where the majority of the population is Muslim, is more inclined to follow the Shafi'i school of thought, this is due to the historical fact that Islam entered Indonesia. We all know that Islam entered Indonesia and was spread by the Wali Sembilan whose spread was very wide throughout the archipelago. The nine guardians mostly follow the Shafi'i madhhab, which makes the spread of Islam more focused on the Shafi'i madhhab(Nashih Nashrullah, 2020)

Meanwhile, according to Sayid Alwi bin Thahir al-Haddad through his book entitled Jana Samarikh min Answer Asilah fi at-Tarikh, the fiqh of the archipelago is indeed closer to the Shafi'i school because the first propagator of Islam to Indonesia was of the Shafi'i school. This is when referring to the theory that the Islamic preacher is a descendant of the Prophet Muhammad whose lineage leads to Imam al-Muhajir

\section{Definition of Ijarah}

Al-Ijarah comes from the word al-ajru or al-iwadh. In the Indonesian language, it means compensation and wages. Al-ijarah (lease) is a contract (agreement) relating to certain benefits (taking benefits of something) so that something is legal to take advantage of by providing certain payments (leases)(Sahroni \& Abdullah, 2011). The word ijarah is derived from the fi'il form "ajara-ya'juruajran." Ajran means the word al-,,iwadh, which means compensation and wages, or can also means lease or wages (Huda, 2011). According to the Fatwa (a binding rule in religion) of National Sharia Board- Indonesian Council of Ulama (DSN-MUI) No. 09/DSN-MUI/IV/2000, Ijarah is a contract for the transfer of usufructuary rights (benefits) of an item or service within a certain period through payment of lease or wages, without being followed by the transfer of ownership of the goods themselves(DSN-MUI: Pembiayaan Ijarah, 2000). Syafi'iyah scholars define ijarah as a transaction for a purposeful, specific, permissible benefit and may be used for certain rewards (Al-Syarbaini \& alKhatib, 2009).

From the definitions above, it can be understood that ijarah is the taking of the benefits of an object if the object is not reduced at all. In other words, the practice of leasing that moves is only the benefit of the object being leased, while the ownership remains with the object's owner. In return for taking the benefits of an object, the lessee is obliged to pay. It can be understood that ijarah is an agreement made by one or several people who carry out a separate and binding agreement, which is made by both parties to give rise to rights and obligations between the two.

Imam Shafi'i said that if a person gives cloth to another person to sell or gives up a house for lease on the basis that the profits will be divided equally between them, then, in this case, Abu Hanifa believes that all these contracts are declared broken. Those who sell or lease out get the same wages as those who do similar work. This wage is taken from the owner of the cloth or the owner of the house(Syafi'i, 2005).

\section{Legal Basis of Ijarah}

The legal bases or references to ijarah (lease) are the Qur'an and Al-ijma'. The legal basis for ijarah in the Qur'an is Surah Al-Thalaq verse 6. Surah Al-Thalaq emphasizes that "if they suckle for you, give them their recompense." (Departemen Agama R. I., 2005). In this case, giving wages is the meaning of ijarah.

Thus, in ijarah, one party hands over the goods to be used by the other party within a certain period, and the other party must pay the lease price they have agreed upon. In this case, ijarah is an act that is mutually beneficial between the two parties who agree (contract).

Terms and Pillars of Ijarah

The terms of the ijarah agreement are associated with several pillars, including:

The terms of the ijarah contract are associated with several pillars, including:

1. Terms related to Aqid (parties who contract/Mu'jir and Musta'jir).

a. According to the Shafi'iyah school of thought, two people who have the contract have reached 
the age of puberty, while according to the Hanafi and Maliki school of thought, the person who has the contract is only at the mumayyiz limit on condition that they get the approval of the guardian. Even the Shafi'iyah group included requirements for Akid, including Rusyd. Rusyd is doing something based on rationality and credibility. So, according to Imam Syafi'iyah, a child who was not mature before Rusyd could not perform the ijarah contract.

b. There is a willingness on both sides or none. The person is making the ijarah contract diffelease in being accessible to will, without any coercion from either party by anyone.

Aqid is the parties who agree, namely the party who leases out or the party of the leased item called "mu'ajjir" and the lessee called "musta'jir," namely the party who benefits from an objectt(Al Jaziri, 1994).

2. Terms related to ma'qud alaih (object of lease)

a. The object of the lease can be handed over, meaning that the leased item belongs to the shah mu'jir (the person who leases it out), and if the musta'jir (the person who leases it) asks for the item at any time, the mu'jir can deliver it at that time.

b. It has a value of benefits according to syara'. The benefits that are the object of the ijarah are fully known by explaining the type and timing of the benefits in the hands of the lessee. Concerning the "benefit period," Imam Syafi'iyah believes that the time of benefit for leased goods must be precise and not cause interpretation. He gave an example; "If someone leases a house for one year with a monthly contract, then the lease transaction is unclear and is considered void." Therefore, the validity of the contract must be repeated every month.

Ma'qud alaih are goods used as objects of lease, in the form of fixed and movable goods, which are the legal property of the mu'ajjir. The criteria for goods that can be leased are everything that can be religiously benefited, and the condition remains intact during the lease period(Al Jaziri, 1994).

c. Wages are known by both parties (Mu'jir and Musta'jir).

d. The object of ijarah can be submitted and is not defective. If there is a defect, the fiqh scholars agree that the tenant has the khiyar right to continue or cancel.

e. The object of ijarah is lawful by syara'.

f. The object is not an obligation for the lessee. For example, hiring people to perform prayers. Imam Shafi'i said it is permissible to receive a salary in teaching the Qur'an because the job of teaching the Qur'an is straightforward. Based on the words of the Prophet, it was the memorizing of the Qur'an as a dowry, while the dowry was usually in the form of wealth. However, the Shafi'i madhhab allows hiring people for Imam Prayer.

3. Conditions related to sighat (ijab and qabul contracts); the requirements related to ijab and qabul are the same as the requirements that apply to buying and selling, except for requirements relating to time. In ijarah, a specific time limit is required. So, a lease (ijarah) with a permanent agreement is not allowed. (Yazid, 2009).

\section{Types of Ijarah}

In terms of object, fiqh scholars divide ijarah contracts into three types:

1. Ijarah 'ain is a lease agreement for benefits directly related to the object, such as leasing land or a house for 1 million a month for one year.

2. Ijarah bil 'amal, namely leases of a work or service nature. Ijarah that is work or service is by hiring someone to do a job. According to fiqh scholars, this type of ijarah is legally permissible if the work is evident, such as construction workers, tailors, factory workers, and shoemakers. This kind of ijarah is divided into two, namely:

a. Personal Ijarah, such as hiring a housemaid.

b. Union Ijarah, namely, a person or group of people who sell their services for the benefit of the people, such as shoemakers, factory workers, and tailors.

Both forms of ijarah for this work (labor, handyman, and helper), according to the fiqh scholars, are legal. 
3. Ijarah bil benefits, namely beneficial lease. Examples of beneficial ijarah are:

a. Leasing a house,

b. Leasing a store,

c. Leasing a vehicle,

d. Leasing clothes,

e. Leasing jewelry and others.

If the benefits of leasing an item are benefits permitted by syara to be used, then the fiqh scholars agree that they may be used as objects of lease (Az-Zuhaili, 2011).

\section{The end of the ijarah contract}

The fiqh scholars state that the ijarah contract will end if:

1. Ijarah is considered expendable if one of the parties to the contract dies, while the heirs are not obligated to destroy it. Meanwhile, according to most scholars, the ijarah is not canceled but will be passed on to the heirs.

2. The occurrence of contract cancellation.

3. The occurrence of a contract of goods being leased. However, there are other scholars' opinions that if there is damage to the leased item, it does not cause the expiration of the ijarah but must be replaced while it can be replaced.

4. Expired the grace period (Az-Zuhaili, 2011).

\section{Waqf}

\section{The Meaning of Waqf}

According to its meaning, waqafa means restraining or preventing, for example, "I refrain from walking." In syara's terms, waqf is a gift whose implementation is carried out by holding back (ownership) of origin, making its benefits generally accepted. Original ownership means holding the waqf property so that it is not inherited, used in the form of being sold, given, pawned, leased, loaned, and the like. Meanwhile, its utilization is to use it according to the will of the waqf giver without compensation(Mughniyah, 2015). It can be interpreted that withholding wealth and giving its benefits in the way of Allah SWT (Sabiq, 2021).

According to the Shafi'i school of thought, it is holding the property taken advantage of while the goods are intact and the property is lost from the waqif and used for something permissible (Lubis, 2010). It means holding back the property that is owned to be used to benefit the people and religion, encouraging Muslims to waqf and continue to seek lawful sustenance from Allah SWT.

Regarding the opinions of these scholars, waqf in Indonesia, as stated in Law Number 41 of 2004 concerning Waqf, is defined as "the legal act of wakif to separate and surrender part of his property to be used forever or for a certain period according to his interests for worship and general welfare according to sharia' (Nizar, 2017).

\section{Legal Basis of Waqf}

Allah has prescribed waqf, advocated, and made it a way of approaching oneself to Allah SWT. Waqf is not explicitly mentioned in the Qur'an, but several verses of the Qur'an that provide instructions and can be used as a reference as a source of waqf law (Wadjdy, 2007).

The allocation of waqf is based on the hadith and as proof of waqf. The hadith tells the story of Umar bin al-Khattab when he obtained land in Khaibar. After he asked the Prophet for guidance about the land, the Prophet advised to withhold the origin of the land and give alms of the results (Manan, 2016).

\section{Terms and Pillars of Waqf}

There are several kinds of conditions and pillars of waqf, namely:

1. People are waqf (wakif). The condition is that people are free to do good, even though they are not Muslims, and do it with their own will, not because they are forced.

2. Objects that are waqf (maukuf). The first requirement is that the object is eternal in substance and can be taken advantage of. Second, belonging to the person who is waqf, even though it is mixed, 
cannot be separated from the others. Third, the waqf property must be received immediately after the waqf is pledged.

3. The purpose of waqf (maukuf alaihi) is required not to conflict with the value of worship.

4. A statement of waqf (sighat waqf), both in oral, written, gesture, or by deed. Currently, very few waqfs are managed productively in the form of a business, the results of which can be utilized for those in need, especially in Indonesia, where there are still many poor people. This utilization is seen from a social perspective, especially for religious purposes. It is effective, but the impact has a less positive influence on the community's economic life. If the designation of waqf objects is not following waqf that can be managed productively, then waqf is a means to realize the socioeconomic welfare of the community will not be realized optimally. Therefore, the notion of productive waqf must be understood by all parties, especially those who directly handle waqf, so that they want to manage waqf assets that have religious and economic benefits(Ghazaly, 2010).

\section{Types of Waqf}

In general, waqf is divided into waqf khairi (solely for charity) and waqf zurri (family waqf). Waqf khairi is grouped into two, namely: (i) general waqf for charitable purposes without specifying the motive, condition (terms) and mauquf'alaih, and (ii) special waqf for charitable purposes by determining the motive, condition (terms), and mauquf' his alias. In waqf zurri, the benefits of waqf are for family purposes. However, some scholars consider this type of waqf a bid'ah, and it does not follow sharia rules (bin Borham, 2011; Nizar, 2017)

In addition, waqf is also grouped into waqf musytarak and waqf irsad. Waqf Musytarak is a combination of waqf between waqf khairi and waqf zurri. A part of the benefits which comes from waqf is dedicated to the benefit of the family and partly to the public. Waqf musytarak is part of waqf istibdal and waqf share. In comparison, waqf irsad is another form of waqf formed by the authority or government originating from Baitul mal property donations as waqf, whether the movable or immovable property (Nizar, 2017)

\section{RESEARCH METHODS}

This research design was field research, namely, research carried out directly in the field to obtain data on the phenomenon of the practice of implementing productive waqf through ijarah contracts at the religious institution of TPQ Al Islamiyyah of Jombang in the perspective of the Syafi'i school of thought. The research approach was a qualitative research approach, which was taken to understand the meaning and process of the research object. Therefore to obtain accurate data, the researcher immediately went into the field and positioned himself as a research instrument which was one of the qualitative research's characteristics. The data obtained from the literature field study was analyzed with a qualitative description. The principles and rules of law obtained were answers to the problems found.

\section{Unit of analysis and research subject}

In this research, it was necessary to have a unit of analysis to focus more on what was studied to avoid bias in concluding. In this research, the unit of analysis related to research was the tenant and nadzir of waqf TPQ Al Islamiyyah in the practice of leasing commercial land on waqf land from the perspective of the Syafi'i school of thought. The research subject was the sources of information that could provide data following the research problems. The research subjects were land tenants, wakif, and nadzir of the TPQ Al Islamiyyah of Jombang's waqf land.

\section{Data Collection Methods}

In this section, the researcher could get accurate and authentic data because it was done by collecting primary, secondary, and tertiary data, which were adapted to the research approach. The primary and secondary data collection techniques used were:

1. A direct Interview

An interview is a face-to-face interpersonal role situation, when someone, namely the interviewer, asks questions that are designed to obtain answers that are relevant to the research problem to the informant. Amiruddin, Introduction to Legal Research Methods,(Amiruddin, 2008). 
Interviews were conducted to obtain information orally to achieve the goal of obtaining accurate information from competent people. In this case, the interviewees were Mrs. Nur Islami as nadzir (waqf manager), Mr. M. Didik as the party who leased the merchandise stall, and Mrs. Sa'adatul Badriyah as the head of the TPA as well as the ustadzah of TPQ Al Islamiyyah, and the family of waqf giver namely Mrs. Hj. Sholihatin

2. Observation

Observation is a method with essential data collection in research, especially research with a qualitative approach. The observation aimed to describe the setting being studied, the activities that took place, the people involved in the activity, and the meaning of the event from the perspective of those involved in the event observed (Poerwandari, 2007).

The observation used in this research was a non-participant observation method by seeing and listening to the situation without actively participating in it (Emzir, 2011). In this observation, the researcher got data about how the stages of leasing the place start from those who provided waqf, waqf recipients, leased out the place of business and until the last stage, namely receiving money and the deadline for leasing.

3. Documentation

This documentation was used to find data regarding records of waqf pledges, waqf charters, and written deeds of lease contracts for leasing a place of business that proved the amount of the lease price, lease period, and other provisions that supported it. Documents in this research were used as reinforcing or supporting data from data that has been obtained from the results of interviews and observations that had been made previously.

\section{Data credibility test}

In this technique, the researcher collected and recorded detailed data about something considered to support the research. The data credibility test used by the researcher was:

1. Triangulation

Triangulation in credibility testing is defined as checking data from various sources in various ways and at various times (Sugiyono, 2005). The data and information that have been collected in qualitative research need to be verified. In testing the veracity of this data, the researcher used a source triangulation technique. To achieve this trust, the following steps were taken:

a. Comparing the results of observations with the results of interviews

b. Comparing what people say in public with what they say in private

c. Comparing the results of interviews with the contents of related documents

2. The Accuracy of Observation

In this case, the accuracy of observation is vital because this research used the observation method. Therefore, there was harmony between the information provided by the informant and the data from observations in the research field.

\section{Data Processing Methods}

The data validity technique was one of the footholds, and the objective basis of the results was qualitative checking. In the technique of checking the data that has been obtained based on the data collection methods mentioned above, the following ways can be done: Edit Stage, Classification Stage, Verification Stage, Analysis Stage, and Conclusion Stage.

\section{Data analysis technique}

The data analysis technique in this research was the Spradley analysis model, namely the qualitative analysis model proposed by James Spradley (Sugiyono, 2005). He suggests four stages in the qualitative research analysis, namely domain, taxonomy, composition, and cultural themes.

\section{Domain Analysis}

The analysis is carried out to obtain a general and comprehensive picture of the social situation under study (Sugiyono, 2005). In this research, the researcher collected what data was needed to get an overview of the practice of leasing and buying stalls in TPQ Al Islamiyyah. All possible data that could be used in this research were collected one by one. 
2. Taxonomy Analysis

This analysis is a continuation of the domain analysis. The data from the domain analysis chosen by the researcher required to be studied further through data collection in the field through interviews, observations, and documentation so that the data became a lot(Sugiyono, 2005). In this research, the researcher began to observe the data according to the categories to obtain a detailed picture of each data regarding the buying and selling stalls used as lease objects - the results of these observations followed by interviews regarding the data obtained to be confirmed.

3. Component analysis

In componential analysis, what is sought to be organized is the difference in the domains or the contrast (Sugiyono, 2005). This data is sought through observation, interviews, or further documentation with triangulation techniques. After finding the similarities in the characteristics or patterns of the taxonomic analysis data, the researchers then carried out more in-depth observations to reveal the description of the leasing practice.

4. Cultural Theme Analysis

According to Faisal (1990) in sugiyono(Sugiyono, 2011), cultural analysis is an effort to find a "common thread" that combines existing cross-domains. By finding the common thread from the analysis of the domain, taxonomy, and componential, it will then be arranged a "building construction" of research objects that were previously still dark to be bright and clear.

The data is in the form of leasing practices by considering the sighat used in the lease agreement and the certainty of the nadzir who becomes the waqf manager that has been processed by component analysis. It may appear that the harmony and terms of the lease from the perspective of the Syafi'i school of thought have emerged. So far, researchers have made preliminary conclusions about the "common thread" of the leasing practice that was applied.

\section{RESULTS AND DISCUSSION}

\section{Productive Waqf Through Ijarah contract at TPQ Al Islamiyyah Jombang}

In this research, the researcher interviewed several who leased the area of selling snacks or places of trade at TPQ Al Islamiyyah Jombang to find out between the tenants and those who leased out the lease business premises. The following were the results of the researcher's interviews with tenants and those who leased out business premises in Jombang as follows:

1. The first-time researchers interviewed Mrs. Nur Islami as nadzir (who manages Waqf).

The managers of Waqf and TPQ development are:

"The waqf in the form of land built by the TPQ building was previously handed over to me. I also became an Al-Qur'an reciting teacher there who also became the leader of the Qur'an teacher. At that time, the waqf giver was the family of Mr. H. Mubardi. Here, we made a written agreement, and we immediately came to the notary deed to be recorded by the notary. This waqf, which I have built the TPQ building, I developed for the activities of reciting the Qur'an, socially, and looking for the economy. So that the TPQ is independent by itself, incidentally, this TPQ is located beside the road. Thank God, the place is strategic too."

The process and the lease fee agreed upon by them were:

"This TPQ is not only a place to recite the Qur'an but also for economic gain. I initially discussed with my friends what if $T P Q$ was built a trading business next time so that this $T P Q$ could be rich by itself. Then, we will temporarily lease the place out first. If there is no one else leasing it, we will manage it ourselves. I will put the lease fee directly into the TPQ construction site. The profit from the business is not put into $T P Q$ 's cash, but the income goes into the tenant's pocket. I do not want to know about his daily income. I only know about the lease because Nadzir agreed to it. The tenant only provides a lease while I provide facilities for places such as stalls. The lease term for this place of business is one year. The cost in a year is 2 million. This lease is paid at the beginning of occupying. Meanwhile, I have increased the lease by 500,000 
because the need for $T P Q$ is also increasing recently. It is to provide wages for those who take care of $T P Q$, who teach diniyah for boarding school students."

The agreement (ijab Qabul) from both parties is:

"At that time, we agreed verbally, and some witnesses were there as well. From myself, the witness was Sa'adatul Badriyah, and from M. Didik as the tenant, Mrs. Sriwati was the witness. The transaction agreement was, "I leased this stall for 2 million, if in the future I increased the lease fee, you have to accept it because the needs can also go up and down because this is for the welfare of TPQ, not for me". After that, the tenant agrees and leases for one year first. Then, I also do not mind if I lease it for one year, but if I want to extend it, it will be discussed again. Then, thank God he extended it again."

The contracts used in this lease were:

"The contracts that I used were only ijarah contracts without any other contracts being used. Because the ijarah contract is a lease of goods or a place while the lessee is leasing a finished place without any other contract that follows".

Furthermore, the obstacles experienced by nadzir (manager) of waqf were:

"From Nadzir's or myself perspectives, there were no difficulties or obstacles that hindered the development of this TPQ. It was just that when I was developing the waqf, it was difficult to find funds to become a perfect TPQ. I looked for help here and there in my way so that this TPQ could develop and become the TPQ that I wanted to be".

The lease (ijarah) was also the same as the existing theory. The conditions made between the tenant and the nadzir have been fulfilled; namely, both parties were of middle age, the object of the lease had been handed over, and the object of the lease had benefits. The benefits were to buy and sell or trade, and the last condition was shighat (ijab qabul). The time limit has also been explained at the beginning of the contract. The tenant only paid money at the beginning of the placement, and the renter got money from the tenant. The agreement between Nadzir and the tenant was an oral agreement with several witnesses. The sound of the ijab qabul was, "I leased this store for 2 million, if in the future I increased the lease, you have to accept it because from needs it can also go up and down because this is for the TPQ's welfare, not for me".

2. The second resource person was Mr. M. Didik as the tenant of the trading stall in the form of a stall selling snacks. In this case, he was the tenant of the place of business. The results of the interview were:

How was the process or payment made to lease this place:

"The lease for this trading business is yearly, not monthly, and I paid at the beginning of the placement. The lease was 2 million. Then, if it was extended, I have not given it, then I must be prepared to be kicked out of this place. Then, in this second year, I extended. In the third year, it was increased by IDR 500,000 (five hundred thousand rupiahs) and became IDR 2,500,000 (two million five hundred thousand rupiahs) per year. The money from TPQ's input was decreasing, and the times were also getting more advanced. So my lease was raised. I am grateful because this way, I could help TPQ finances."

Meanwhile, the rules for leasing this place and the facilities were:

"The facilities that I received were just a place, while for electricity, cleanliness, and so on, it was my responsibility. The foundation did not provide such facilities. Since it was not the responsibility of the one who gave this place, it was my responsibility."

While the pillars and conditions for the contract were:

"I agreed at the beginning of the lease so that one day there would be no misunderstanding between us. Nadzir also explained the place we were going to use before I agreed. Nadzir came to the place to find out how the tenants had to manage the place. I did the Ijab Qabul with Nadzir. Moreover, the content of the agreement was, "I leased this shop for 2 million, if in the future I increased the lease, then you 
have to accept it because needs can also go up and down. It was for the TPQ's welfare, not for me" and that was where I did a transaction with Nadzir, " after that we received it "I accept this place. If there is damage when I use it, then I will replace it". After that, we managed this place until now."

It was the opinion of Mr. M. Didik as the tenant of the stall. The contract used was clear that it was an ijarah contract because the payment was made at the beginning of the placement of the place without making installments or anything else. Then, the time limit for payment and benefits has also already existed, namely Mr. Didik's snack business. Mrs. Sri Wati as a witness from Mr. M. Didik, has reached puberty. So, those who made the contract were valid and allowed in the teachings of Islam.

3. The third resource person was from the TPQ management by Mrs. Sa'adatul Badriyah. She was the head of TPQ.

How was the development, and how the waqf was carried out:

"This waqf was handed over to Mrs. Nur Islami. Then, the waqf was developed and became what it is nowadays. In addition, this TPQ was used as a place to trade so that the TPQ could progress on its own without the intervention of others. The lease fee was IDR 2,000,000 (six million rupiah/3 years). If the lease is not extended, the tenant must be prepared to be evicted from the place. Then, in the third year, the lease was increased by IDR 500,000 (five hundred thousand rupiahs) and became IDR 2,500,000 (two million five hundred thousand rupiahs) per year. The contract used was the ijarah contract (lease) because it was clear that the lease was ijarah".

How to carry out their agreement:

"They agreed verbally because the tenants did not want to make it difficult for themselves. So, they agreed verbally. I was a witness from Nadzir's side. The agreement was, "I lease this store for two million, if in the future I increase the lease, then you have to accept it because from needs it can also go up and down because this is for the TPQ's welfare, not for me." Then, from Mr. Mulyono's side, he also agreed with what Mrs. Nurul said. That was where this transaction took place".

Therefore, the waqf land has developed well, and the TPQ can also earn their own money. Both parties have also mutually agreed with the rules given by the renter, namely the initial payment. The contracting parties were also mature because they were adults (married). The object of the lease was also transparent, which has benefits, namely for a place for trading (buying and selling) snacks.

The income from the TPQ to renovate the building was from the rent. During the construction of the TPQ, Nadzir faced many obstacles. She sometimes runs out of money to continue building this TPQ. However, she did not give up, and she got satisfactory results from the TPQ's construction.

From the results of observations and documentation carried out by researchers to find research data related to waqf land being leased, it was found that the initial handover of waqf from wakif to nadzir did not mention the prohibition on the management of the waqf. It was evidenced by the documentation of the waqf submission, which was fully submitted to nadzir, the waqf management. On this basis, Nadzir was free to develop the function of part of the waqf land to be leased out and re-utilize the waqf.

Then from the results of interviews with tenants, nadzir, and some ustadz, as well as supported by several documents regarding the lease agreement, several temporary conclusions can be drawn:

1. All the perpetrators of this ijarah contract, starting from Mr. M. Didik as the tenant and Mrs. Nur Islami as the waqf manager, had reached puberty and were in good health.

2. The tenant was aware and accepted all the provisions given by Nadzir when the ijarah contract was implemented.

3. During the implementation of the ijarah contract, the things contained in the ijarah contract, such as the lease period, lease price, and provisions relating to the equipment where everything has been conveyed in the contract. 
4. All documents regarding waqf and waqf land management were still there and maintained.

5. The family of the waqf provider did not question the development of TPQ waqf land in the form of ijarah.

Some ordinary people could not accept the practice of ijarah for economic activities on waqf land that has been functioned for religious activities above. They understood that the land that had been waqf could not be used other than religious matters. It was because the practice was considered to be out of the primary purpose of waqf. Therefore, the researcher tried to explain the practice of ijarah on waqf land from the perspective of the Syafi'i madzhabl of thought.

\section{Productive Waqf through Ijarah Contracts at TPQ Al Islamiyyah in the Perspective of the Syafi'i Madzhab of thought.}

The contract will not be valid except by using sighat ijab qabul. It is the original law in buying and selling, leasing, marriage, freeing slaves, and other contracts. The origin in all contracts is consensual (Salim, 2008). The development of productive waqf through this ijarah contract means in the waqf land given to Mrs. Nur Islami. She developed the waqf land with many people, including his family and the surrounding communities. She was also confused about finding funds to renovate the TPQ. What used to be waqf was just a piece of vacant land planned to be a TPQ. She has been a Qur'an teacher at home who did not fit the number of students who recited the Qur'an. It was where he wanted to build his TPQ building.

He wanted the TPQ to be rich on its own, meaning that he wanted the TPQ to make money on its own. She thought about what if the first floor was made for a place of business. After that, it became a place of business, and some leased the place to be used as a place of business. The person who leased the place was Mr. M. Didik, who ran a hawker trading business. It was because the potential for snacks around TPQ was very strategic. After all, there were many students or the general public. Of these tenants, on average, they leased the place for one year. In one year, he paid a lease of two million. It was paid at the beginning of the rent. Between Mrs. Nur Islami and Mr. M. Didik, they made an ijab qabul, namely the lease period was one year, but if it was more than one year, the tenant had to leave the place because it was due pay if you wanted to extend it. The contents or pronunciation of the ijab qabul were: "I leased this shop for two million. If in the future I increase the lease, then you have to accept it because, from needs, it can also go up and down because it was for the TPQ's welfare, not for me." Mr. Didik accepted, "I accepted this place, and If there is damage when I use it, I will replace it."

In this case, they were legitimate to make a contract or agreement because they met the conditions, namely Muslims, baliq (said baliq because they were adults and married), independent, and intelligent (not crazy). According to Imam Shafi'i, ijarah is defined as that which is cut off from the owner's property, transferred to the person to whom the owner belongs. If it is owned by the one who leases it, it will benefit. So, leasing is not like that. Ownership of the slave remains with the owner. Its benefits are for those who lease up to the crucial period(Syafi'i, 2005).

As in this lease contract, the lease was used to develop a trading business. Those who leased out got a reward, while those who leased got a place to do business. It can be concluded that the object of the lease had the benefits of conducting a trading business or buying and selling snacks. According to Imam Ash-Shafi'i, there are three kinds of conditions for ijarah, namely:

1. Existing Conditions (requirements of al-in'iqad), according to Imam Shafi'i, the condition for being to be mature and reasonable is an ijarah contract because it is a contract that gives ownership rights in life so that it is the same as buying and selling (Zuhaili). Mrs. Nur Islam with Mr. M. Didik were adults and have reached the age of puberty to make the contract.

2. Applying Conditions (syarth an-nafaadz), according to Imam Shafi'i, the condition was that there was no ownership or power. The land was given to Mrs. Nur Islam for about ten years.

Valid conditions (ash-shihhah conditions). From this condition, there were seven kinds of conditions, namely:

1. The willingness of the two contract actors,

2. The nature of the contract object (i.e., benefits) should be known to avoid disputes.

3. Explanation without benefit, 
4. Explanation of the period,

5. Ijarah musyaharah (monthly rent),

6. Explanation of the work object,

7. Determination of time and work object at the same time

In TPQ, which was leased out to develop a business, the object of the contract was to explain the "period." According to Imam Shafi'i, the explanation of the period that the determination of the initial period of the contract was a condition that must be mentioned in the contract. In the absence of a determination, the period was unclear, so the object of the ijarah contract became unclear (Zuhaili). The lease period for the stalls used for trading businesses was one year, and the initial payment was without installments or anything else. The agreement agreed verbally, and there were also witnesses.

According to Imam Shafi'i, the determination of the time and the object of work is simultaneous. In his most authentic opinion, it is not permissible to lease work, such as sewing clothes, to combine time and the object of work. Therefore, it is not legal to determine to the tailor a time limit, such as a day, a week, and so on. If that happens, then the ijarah contract is invalid or void. The action includes gharar with the possibility that the object will not be completed within a day or a week because the work may be completed earlier or later(Az-Zuhaili, 2011). In Imam Asy-Shafi'i's opinion, the sewing work cannot be limited because the work can sometimes be completed quickly, and it can take a long time too. Meanwhile, leasing a place for trading business can be given time because it could be that the renter is not satisfied with the facilities provided by the owner of the place.

Imam Shafi'i said waqf is a legal action that is prescribed. Then, the imams of the four madhhabs also agree with Imam Shafi'i that the waqf of the mosque, the waqf of the cottage, and the others are not intended to benefit the waqf to certain people and are also not owned by someone. However, they have different opinions regarding the purpose of waqf to benefit certain people. These differences are viewed in terms, namely in terms of ownership and in terms of the necessity of waqf (Syalthut, 2000).

This TPQ used Imam Shafi'i's opinion. The treasures given to all of us are only a deposit from Allah and later will also return to Allah. Therefore, as Muslims, we must help each other for others. Being a human must also help do not to be a person. As with land that has been waqf, it will be helpful if Nadzir manages it well. The land that was built in such a way and became a building there is made for a place of worship and also as a place to look for a bite of rice. Tenants also have the benefit of using a place to find sustenance there. From the property rights, it must also be true who legally owns the place. As in the TPQ, Mr. H. Mubardi was a waqf giver and gave it to Mrs. Nur Islami as nadzir (manager).

Thus, the development of productive waqf through the ijarah contract based on Imam Syafi'i's opinion was permissible to lease in the waqf land. However, it must be used in the way of Allah and should not be used in the wrong way. Pillars and conditions must also be met for this lease to be valid in Islamic law and can develop without any dispute from the parties.

The pillars and terms of the lease or ijarah include:

1. Mu'jir and Musta'jir (people who make lease contracts or wages) must be mature and have good sense.

In this case, both Mrs. Nur Islami and Mr. M. Didik were adults and had reached puberty to make the contract.

2. Goods leased out or done for wages include the benefits of land built by TPQ and store land for rent. In this case, the land had benefits because the land could be used to earn income for daily life.

3. Ujrah, whose amount is known by both parties.

The tenant got a place to trade, while the lessee got the rent.

4. As well as sighat ijab qabul between Mu'jir and Musta'jir (people who make lease contracts or wages). There was an agreement between the tenant and the lessor, namely the payment at the beginning of the placement, and if it was due but has not been extended, the tenant was obliged to leave the place (Suhendi, 2002). 
The waqf land established by TPQ would be even better if the TPQ itself could make money without help from other people. Then, the TPQ could get money from the lease of the place used by the trading business so that the TPQ could be independent to make money from these incomes. Then, these incomes were used to develop TPQ so that it could be maintained.

The results of the explanation above were answers to various public concerns regarding the practice of ijarah carried out by nadzir of waqf TPQ AL Islamiyyah of Jombang. Based on the results of field studies and combined with the perspective of the Imam Syafi'i school of thought, everything that has been carried out has complied with sharia provisions. Even so, they still could not accept it gracefully because they have already had a basic understanding of waqf that has never had an effective waqf practice. They made various arguments ranging from the psychology of the wakif family to asking whether the money from the lease would go to nadzir or TPQ.

\section{CONCLUSION}

The development of productive waqf through ijarah contracts at religious, educational institutions in the form of TPQ used an ijarah contract (lease) because this transaction used a time limit. In this case, the contract of leasing a trading business place carried out by nadzir uses time per year. There was an agreement from the beginning that the leased productive land would be used to carry out a trading business. Then, the money from the lease went into TPQ's cash to develop TPQ to become advanced. At the same time, the TPQ could also make their own money without any outside help. Then, the lease of the place was only temporary, not forever.

According to the Imam Shafi'i School, the agreement between the two parties to the contract was valid because the pillars and conditions have been fulfilled. The agreement was valid according to Islamic law. There was no doubt about making the ijarah contract at TPQ Al Islamiyah of Jombang.

Practicing productive waqf through the ijarah contract could significantly benefit the surrounding community and the TPQ institution. Trade stall tenants could earn income by selling snacks to students who were studying the Qur'an. For TPQ institutions, they felt helped and were not confused when they were going to renovate the building because they got lease money that went to the TPQ agency's treasury. In addition, it was also not confusing to give the salaries of the ustadz at the end of each month nowadays. Because before practicing productive waqf, they have relied on the monthly fees of the students, which were not smooth so far.

\section{Practical Implications}

Based on the results of this study, it is recommended for people who manage waqf (Nadzir) to always pay close attention to sharia provisions if the waqf property will be used productively, especially through ijarah contracts. Nadzir may manage the waqf property according to his will on the basis that public benefits can be achieved and from the family or the general public understand and understand the innovations carried out and have a deep understanding of the rules of Islamic sharia. In this way, the waqf property will develop its usefulness and be more productive.

For the community, they can better understand that waqf assets managed by nadzir can be used more productively and increase benefits. This is because so far the understanding of the community is very limited and it is known that waqf assets must be managed according to the intentions of the person who is waqf. And sometimes the family of the person who is waqf still acts as the owner when Nadzir wants to innovate, with the permission of the family.

For academics, this research can be an inspiration to be able to conduct a more in-depth study of the utilization of waqf management. In addition, it can also be the basis for conducting research related to waqf of assets other than land or building waqf.

\section{Limitations and future research}

This research is limited to the general application of ijarah contracts to waqf assets in the form of buildings or plots of land. Future studies should be able to analyze ijarah more deeply and from waqf property other than buildings or land. The second limitation relates to the practice of ijarah which is only very basic. Therefore, future research should be able to explore more in-depth ijarah with various kinds, and also from other contracts. Another limitation of this research is that it is only still peeling from the perspective of the Syafi'i madhhab fiqh. Henceforth, we can explore productive waqf practices 
Azizuddin, et al/Jurnal Ekonomi Syariah Teori dan Terapan Vol. 8 No. 6 November 2021: 757-770

from various schools of thought in Islamic sharia.

\section{REFERENCES}

Al-Syarbaini, S. M. I. M., \& al-Khatib, E. (2009). Mughni al-muhtaj ilâ ma rifah ma ânî alfadz alminhaj, juz 2. Beirut: Dar Al-Khatab Al-Ilmiyah.

Al Jaziri, A. R. (1994). Al fiqh a'la al Mazahib al Arbaa'h. Maroko: Dar Alhadis.

Amiruddin. (2008). Pengantar metode penelitian hukum. Jakarta: PT. RajaGrafindo.

Az-Zuhaili, W. (2011). Al-figh al-islam wa" dillatuhu jilid x terjemahan Abdul al-Hayyi Qotani, dkk. Jakarta: Gema Insani \& Darul Fikir.

Bin Borham, A. S. (2011). Pelaksanaan pembangunan wakaf korporat Johor Corporation Berhad (JCorp): Satu tinjauan. In International Conference on Humanities, 1-13

Departemen Agama R. I. (2005). al-Qur'an dan terjemahnya. Jakarta: J-Art.

Emzir, A. D. (2011). Metodologi penelitian kualitatif. Jakarta: Rajawali Pers.

Fahri, M. B., \& Zaki, I. (2018). Strategi manajemen pengelolaan wakaf produktif di pesantren yayasan arwaniyyah Kudus. Jurnal Ekonomi Syariah Teori dan Terapan, 5(8), 699-712. http://dx.doi.org/10.20473/vol5iss20188pp699-712

Ghazaly, A. R. (2010). Fiqh muamalat. Jakarta: Kencana.

Hafidhuddin, D., \& Antonio, M. S. (2004). Hukum wakaf. Jakarta: Iman dan Dompet Duafa Republika.

Huda, Q. (2011). Fiqh muamalah. Yogyakarta: Teras.

Kementerian Agama RI. (2021). Data Tanah Wakaf. Diakses dari http://siwak.kemenag.go.id/

Lubis, S. K. (2010). Wakaf dan pemberdayaan umat. Jakarta: Sinar Grafika.

Manan, D. (2016). Wakaf produktif dalam perspektif imam madhab. Jurnal Mahkamah: Kajian Ilmu Hukum Dan Hukum Islam, 1(2), 363-382.

Mohamad Akhir, N. S., Abdullah, S. R., Mohammed Ghazali, A., Mohd Yusof, A. S., \& Hussin, R. (2019). Integrasi wakaf dan ijarah: Alternatif dalam kelestarian sekolah tahfiz swasta di Malaysia. In International Conference on Zakat, Tax, Waqf And Economic Development (ZAWED), 1st - 2nd December 2019, Malaysia.

Mughniyah, M. J. (2015). Fiqih lima mazhab: Ja 'fari, Hanafi, Maliki, Syafi 'i, Hambali (Gold Edition). Jakarta: Shaf e-publishing.

Nashih Nashrullah. (2020). Alasan Indonesia bermazhab syafii menurut petualang Maroko. Diaksed dari https://www.republika.co.id/berita/q5m809320/alasan-indonesia-bermazhab-syafiimenurut-petualang-maroko

Nizar, M. A. (2017). Development of productive waqf in Indonesia: Potential and problems. https://mpra.ub.uni-muenchen.de/97967/

Oktarina, A., \& Asnaini, A. (2018). Developing models of productive waqf masjid agung syuhada Yogyakarta. QIJIS (Qudus International Journal of Islamic Studies), 6(1), 103-126. DOI: http://dx.doi.org/10.21043/qijis.v6i1.3719

Poerwandari, E. K. (2007). Pendekatan kualitatif untuk penelitian perilaku manusia. Depok: LPSP3 Fakultas Psikologi Universitas Indonesia.

Sabiq, S. (2021). Fikih sunnah, jilid 2 volume 5. Jakarta: Cakrawala Publishing.

Sahroni, S., \& Abdullah, R. (2011). Fikih muamalah. Surabaya: Ghalia Indonesia.

Salim, A.-S. (2008). Sahih figh as-sunnah wa adillatuhu wa taudih mazahib al-a'immah, Beirut: Dar Al-Khatab Al-Ilmiyah.

Sudarwan, D. (2002). Menjadi peneliti kualitatif. Bandung: Pustaka Setia.

Sugiyono. (2011). metode penelitian kuantatif, kualitatif, dan R\&D. Bandung: CV. Alfabeta.

Sugiyono, P. (2005). Memahami penelitian kualitatif. Bandung: CV. Alfabeta.

Suhendi, H. (2002). Fiqih muamalah. Jakarta: PT. Raja Grafindo Persada.

Syafi'i, I. (2005). Mukhtashar kitab al umm fi al-fiqh. Jakarta: Pusata Azzam.

Syalthut, M. (2000). Muqaranatul madzaahib fil fiqhi, terj abdullah zakiy al-kaaf. Bandung: Pustaka Setia.

Wadjdy, F. (2007). Mursyid, wakaf dan kesejahteraan umat. Yogyakarta: Pustaka Pelajar.

Yazid, A. M. (2009). Fiqih muamalah dan implementasinya dalam lembaga keuangan syari'ah. Yogyakarta: Logung Pustaka. 